\title{
FIRST ISOLATION OF LEPTOSPIRES FROM DAIRY GOATS IN BRAZIL
}

\author{
Walter Lilenbaum ${ }^{1 *}$; Zenaide M. Morais²; Amane Paldês Gonçales²; Gisele O. de Souza² ${ }^{2}$ Leonardo Richtzenhain²; \\ Silvio A. Vasconcellos ${ }^{2}$
}

${ }^{1}$ Laboratório de Bacteriologia Veterinária, Departamento de Microbiologia e Parasitologia, Universidade Federal Fluminense, Niteroi, RJ, Brasil; ${ }^{2}$ Departamento de Medicina Veterinária Preventiva e Saúde Animal, Faculdade de Medicina Veterinária e Zootecnia, Universidade de São Paulo, São Paulo, SP, Brasil.

Submitted: April 09, 2007; Returned to authors for corrections: May 20, 2007; Approved: July 17, 2007.

\section{SHORT COMMUNICATION}

\begin{abstract}
Leptospires have never been recovered from goats in Brazil. Serum samples were obtained from 248 goats from Rio de Janeiro and from the seroreactive animals, urine samples were collected and processed for Leptospira isolation. A total of 52 positive reactions were observed, corresponding to $20.9 \%$ of the samples. The most prevalent reactions were to serovars Hardjo (36.5\%), Shermani (30.8\%), Icterohaemorrhagiae (9.6\%), Grippotyphosa (9.6\%), Autumnalis (5.8\%), Castellonis (3.8\%) and Bratislava (3.8\%). Two strains of Leptospira sp. were isolated, both in the same region, but from different flocks. Presumptive identification based on serologic methods suggests those strains to be from Grippotyphosa serogroup.
\end{abstract}

Keywords: Goats, leptospirosis, Leptospira sp.

Dairy goat breeding is an increasing economic activity in Brazil (1). In spite of the large number of animals, approximately 12 million, Brazil ranks as only $18^{\text {th }}$ in terms of the amount of goat milk produced (4), mainly due to the low per goat milk productivity. Amongst other factors, infectious diseases such as leptospirosis may contribute to this problem, leading to impaired milk production.

Goats are known to be less susceptible to leptospirosis than other domestic species, as cattle (9). Leptospirosis in goats may present in an acute form, with an increase in body temperature, anorexia, depression, jaundice, and anaemic or haemorrhagic syndromes (5). Nevertheless, the chronic form with impaired fertility, neonatal deaths, abortions and decreased milk production occurs more frequently, leading to important economic losses $(2,10)$. In several states of Brazil, serological evidence of the disease has been reported since the 60's (7). In spite of previous reports that suggest the strong impact of leptospirosis on reproductive efficiency (10), leptospires have never been recovered from clinical samples of goats in Brazil.
Thirteen flocks located in several regions of the state of Rio de Janeiro, in order to significantly represent the whole state, were studied. Flocks comprised 60-350 adult animals. Flocks and total blood samples were chosen and collected randomly from about $20 \%$ of the flock in each area. Besides location, the existence of a reliable identification system of the goats and the absence of a vaccination program against leptospirosis were the only inclusion criteria. Although it was not an inclusion criterion, all flocks presented a certain level of lowered fertility. The most frequent reproductive problems identified were estrous repetition and low conception rates (all flocks), premature calving ( 8 flocks) and sporadic abortion (8 flocks).

In July 2006, serum samples were obtained from 248 adult (15 years old) goats. Blood was collected in Vacutainer tubes from the jugular vein of each goat. Samples were chilled and transported to the laboratory where they were centrifuged at $1000 \mathrm{~g}$ for $10 \mathrm{~min}$. Serum was kept in $1.5 \mathrm{~mL}$ Eppendorf tubes and stored at $-20^{\circ} \mathrm{C}$ for batch testing. Samples were examined for Leptospira antibodies by the microscopic agglutination test

*Corresponding Author. Mailing address: Laboratório de Bacteriologia Veterinária, Departamento de Microbiologia e Parasitologia, Universidade Federal Fluminense, 24210-130, Niterói, RJ, Brasil. Tel. +55-21-2629-2435; fax: +55-21-2629-2432. E-mail: mipwalt@vm.uff.br 
(MAT), using live antigens grown in liquid medium (EMJH) free of contamination or self-agglutination. A complete panel of 24 strains of live Leptospira were used as antigens L. biflexa serovars Andamana and Patoc; L. interrogans serovars Australis, Autumnalis, Bataviae, Bratislava, Canicola, Copenhageni, Icterohaemorrhagiae, Pomona, Sentot and Wolffi; L. borgpetersenii serovars Castellonis, Hardjo, Hebdomadis, Javanica, Pyrogenes, Tarassovi and Whitcombi; L. kirschneri serovars Butembo, Cynopteri and Grippotyphosa; L.noguchi serovar Panama and L. santarosai serovar Shermani. Samples that showed agglutinating activity at 1:50 dilution had the antibody titres further tested by twofold serial dilutions. Samples were considered as reactive when agglutination was evident on a 1:100 dilution. The antigen with the highest titre was considered to be the infective serovar (5).

From the seroreactive animals, urine samples were collected after an intravenous injection of furosemide at a rate of $150 \mathrm{mg}$ per goat, and the second voiding of urine was collected into sterile vials, very carefully to avoid contamination. Urine samples were immediately added to a culture medium (EMJH) in a $10 \%$ concentration and transported to the laboratory at room temperature.

In the laboratory, samples were seeded using the serial dilution technique to $10^{-2}$ and $10^{-3}$ dilutions into Fletcher's semisolid medium added with 5-Fluorouracil $300 \mathrm{mg} / \mathrm{L}$ and Nalidixic acid $20 \mathrm{mg} / \mathrm{L}$ and incubated for $24 \mathrm{~h}$ at $28^{\circ} \mathrm{C} \mathrm{(13).} \mathrm{After}$ $24 \mathrm{~h}$ of incubation, tubes were seeded into Fletcher's semisolid medium without antibiotics, incubated at 28 to $30^{\circ} \mathrm{C}$ and examined weekly under dark field microscopy during six weeks. Intraperitoneal inoculation of $0.5 \mathrm{~mL}$ of each urine sample (diluted $10 \%$ in EMJH medium) in young/adult (80 to $120 \mathrm{~g}$ body weight) hamsters (Mesocricetus auratus) was also performed. After inoculation, hamsters were examined daily. Upon the appearance of suggestive signs of leptospirosis, the animals were sacrificed at any time. Animals that did not develop clinical signs of the disease were sacrificed only at the $21^{\text {st }}$ day post-inoculation.

Kidney samples of the hamsters were then inoculated into two tubes of Fletcher's semisolid medium without antibiotics, incubated at 28 to $30^{\circ} \mathrm{C}$ and examined weekly under dark field microscopy during six weeks. Blood samples were also collected for serology.

Isolated strains were presumptively identified through the microscopic agglutination test (MAT). The hamster serum was tested against a panel of 24 serovars and isolated strains were tested for a specific polyclonal antiserum panel representative of the pathogenic serogroups, kindly offered by Dr. A. Schonberg, Germany. Definitive identification of isolated strains are under processing at the Pasteur Institute, Paris, France, using genetic tools as Pulsed Field Gel Electrophoresis (PFGE) (8) and Variable Number Tandem Repeats (VNTR) (11).

A total of 52 positive reactions were observed, corresponding to $20.9 \%$ of the samples. The most prevalent reactions were to serovars Hardjo (36.5\%), Shermani (30.8\%), Icterohaemorrhagiae (9.6\%), Grippotyphosa (9.6\%), Autumnalis (5.8\%), Castellonis (3.8\%) and Bratislava (3.8\%), according to Table 1 . The rate of seroreactivity ranged from $10.5 \%$ to $46.4 \%$ of the examined group. Goats are not a maintenance population for Hardjo; the infection occurs due to cattle contact, since the bovine is the maintenance for this serovar (12). The rate prevalence of $20.9 \%$ and predominance of Hardjo were not unexpected for this population and are consistent with recent reports of seroprevalence of leptospirosis in Brazil, either in goats or bovines (7). It is higher, however, than the $11.1 \%$ that was recently reported in the same region (10).

In cattle, leptospiral infection has been classified into two major groups: one consisting of strains adapted to and carried by cattle, such as Hardjo, which are independent of region or rainfall; and a second that consists of incidental infections caused by strains carried by other domestic and free-living animals, which are dependents on environmental factors and farm management practices (3). It has been suggested that the second group could be relatively more important in tropical countries than in other regions. It is also widely accepted that this classification is valid for other species, as sheep and goats. Therefore, seroreactivity observed against Icterohaemorrhagiae or Grippotyphosa should most probably be considered as incidental infections and therefore strongly related to environmental conditions.

Two strains of Leptospira sp. were isolated, both in the same region (rural area of Nova Friburgo, RJ), but from different flocks. Strain M72/06-6 as recovered from a 4 year-old female that had presented seroreactivity to serovar Grippotyphosa, titre 400. This animal has not presented clinical signs that could suggest leptospirosis. Other goats from the same flock also presented seroreactivity with titres ranging from 100 to 400 , but no other Leptospira strain was recovered from this flock. This

Table 1. Prevalence of Leptospira serovars in dairy goats from Rio de Janeiro, Brazil.

\begin{tabular}{lccc}
\hline \multicolumn{1}{c}{ Serovar } & No. Samples & Reactives $(\%)$ & Total $(\%)$ \\
\hline Hardjo & 19 & 36.5 & 7.7 \\
Shermani & 16 & 30.8 & 6.4 \\
Grippotyphosa & 5 & 9.6 & 2.0 \\
Icterohaemorrhagiae & 5 & 9.6 & 2.0 \\
Autumnalis & 3 & 5.8 & 1.2 \\
Castellonis & 2 & 3.8 & 0.8 \\
Bratislava & 2 & 3.8 & 0.8 \\
Sub-total & 52 & 100 & 20.9 \\
Non-reactives & 196 & - & 79.1 \\
\hline Total & 248 & - & 100 \\
\hline
\end{tabular}


flock was located close to a small river and the owner reported occasional flooding during rainy season, what was considered to be the most probable source of the infection. Presumptive identification based on serologic methods suggests this strain to be a Grippotyphosa strain (specific titre 51,200).

The other strain (M72/06-13) was recovered from a threeyear old male, with no clinical signs or leptospirosis and apparently without detectable reproductive disorders. Fertility of this animal was reported to be satisfactory and it had presented seroreactivity for both Hardjo and Grippotyphosa at the same intensity, titre 200. In spite of many efforts, particularly in other three seroreactive animals, no leptospires were isolated from other animals of the same flock. No flooding or watercourses were observed in this farm and the source of the infection could not be determined. Presumptive identification based on serologic methods also suggests this strain to be a strain from Grippotyphosa serogroup (specific titre 12,800).

Isolated strains were proved to be virulent, since they killed young hamsters before 10 days after inoculation. Both isolated strains were able to kill the hamsters; nevertheless, although strain M72/06-6 killed the hamster without the development of visible specific signs, strain M72/06-13 determined unusual neurological symptoms in the inoculated hamster, as convulsions and hyperestesia. From this hamster leptospires were recovered not only from the kidneys, but also from brain samples, collected at necropsy.

Recovery of leptospires from asymptomatic animals is not easy. In spite of the difficulties inherent to the growth of the bacterium and to the possibility of contamination of the urine samples, excretion of viable bacteria in urine is intermittent and only occurs during a reduced and uncertain period after contamination (5). This is the reason why the majority of studies on animal leptospirosis are conducted after serological findings. Although Grippotyphosa strains have already been associated to incidental leptospirosis in goats, including some cases of abortions (9), clinical signs determined by this infection are usually mild. Grippotyphosa is a typical environmental strain of Leptospira sp. Consequently, infection of goats depends to a greater extent on the possibilities of contact with these microorganisms in their natural and habitual environment. Due to the complex ecology of leptospirosis, this serovar has also been described in cattle (6) as well as in horses in Brazil (7).

Concluding, the recovery of leptospires from dairy goats, by the first time in Brazil, unquestionably confirms the occurrence of this infection in caprines in the country. Nevertheless, since the isolated strains most probably belongs to the Grippotyphosa serogroup, an environmental strain associated to incidental infections, a more elaborated discussion on caprine leptospirosis and its economic and sanitary impact in Brazil is not possible. Therefore, broader studies and a significant effort of researchers become necessary in order to obtain other isolations of the agent from this species and allow a comprehensive understanding of the real impact of leptospirosis in goat breeding in Brazil.

\section{ACKNOWLEDGEMENTS}

This study was supported by FAPERJ - Research Support Foundation of Rio de Janeiro, Brazil. WL, LR and SAV are research fellows of CNPq- Brazil. The aa. would like to thank the collaboration of Dr. P. Ristow and Mr. G. B. Cavalcanti for their help.

\section{RESUMO}

\section{Primeiro isolamento de leptospiras em caprinos no Brasil}

Leptospiras nunca foram isolados de caprinos no Brasil. Amostras de soros foram obtidas de 248 caprinos no Rio de Janeiro, e, dos animais sororeativos, amostras de urina foram coletadas e processadas para isolamento de leptospiras. Um total de $52(20,9 \%)$ reações positivas foi observado. Os serovares mais prevalentes foram Hardjo $(36,5 \%)$, Shermani $(30,8 \%)$, Icterohaemorrhagiae (9,6\%), Grippotyphosa $(9,6 \%)$, Autumnalis $(5,8 \%)$, Castellonis $(3,8 \%)$ e Bratislava ( $3,8 \%)$. Duas estirpes de Leptospira sp. foram isoladas, ambas na mesma região, mas de diferentes rebanhos. A identificação sorológica presuntiva sugere trataram-se de amostras do sorogrupo Grippotyphosa.

Palavras-chave: caprinos; leptospirose; Leptospira sp.

\section{REFERENCES}

1. Cordeiro, P.C. (2006). Mercado do leite de cabra e de seus derivados. Ver. $C F M V, 39,19-23$.

2. Cunha, E.L.P.; Mota, R.A.; Meireles, L.; Silva, A.C.C.; Silva, A.V.; Langoni, H. (1999). Pesquisa de Aglutininas anti-Leptospira em soros de caprinos no estado de Pernambuco, Brasil. Rev. Bras. Med. Vet. $21,38-40$

3. Ellis, W.A. (1984). Bovine leptospirosis in the tropics: prevalence, pathogenesis and control. Prev. Vet. Med., 2, 411-421.

4. FAO: Food and Agricultural Organization. Downloaded from http:// www.fao.org,

5. Faine, S.; Adler, B.; Bolin, C.; Perolat, P. (2000). Leptospira and Leptospirosis, second edition. MedSci, Melbourne, Austrália. 272pp.

6. Favero, M.; Pinheiro, S.R.; Vasconcellos, S.A.; Morais, Z.M.; Ferreira, F.; Ferreira Neto, J.S. (2001). Leptospirose bovina - variantes sorológicas predominantes em colheitas efetuadas no período de 1984 a 1997 em rebanhos de 21 estados do Brasil. Arq. Inst. Biol., 68(2), 29-35.

7. Favero, A.C.M.; Pinheiro, S.R.; Vasconcellos, S.A.; Morais, Z.M.; Ferreira, F.; Ferreira Neto, J.S. (2002). Serovares de leptospiras prevalentes em exames sorológicos de bubalinos, ovinos, caprinos, eqüinos, suínos e cães de diversos Estados brasileiros. Ciência Rural 32, 613-619.

8. Herrmann, J.L.; Baril, C.; Bellenger, E.; Perolat, P.; Baranton, G.; Saint Girons, I. (1991). Genome conservation in isolates of Leptospira interrogans. J. Bacteriol., 173(23), 7582-8. 
9. Leon-Vizcaino, L.; Mendoza, M.H.; Garrido, F. (1987). Incidence of abortions caused by leptospirosis in sheep and goats in Spain. Comp. Immun. Microbiol. Inf. Dis., 10, 149-153.

10. Lilenbaum, W.; Souza, G.N; Ristow, P.; Moreira, M.C.; Fraguas, S.; Cardoso, V.S.; Oelemann, W.M.R. (2007). A serological study on Brucella abortus, caprine arthritis-encephalitis virus and Leptospira in dairy goats in Rio de Janeiro, Brazil. The Vet. J., 173, 408412 .

11. Salaun, L.; Merien, F.; Gurianova, S.; Baranton, G.; Picardeau, M. (2006). Application of multilocus variable-number tandem-repeat analysis for molecular typing of the agent of leptospirosis. J. Clin. Microbiol., 44(11), $3954-62$.

12. Schollum, L.M.; Blackmore, D.K. (1981). The serological and cultural prevalence of leptospirosis in a sample of feral goats. New Zealand Vet. J., 29, 104-106.

13. Vasconcellos, S.A.; Oliveira, J.C.F.; Morais, Z.M.; Baruselli, P.S.; Amaral, R.; Pinheiro, S.R.; Ferreira, F.; Ferreira- Neto, J.S.; Schönberg, A.; Hartskeerl, R.A. (2001). Isolation of Leptospira santarosai, serovar guaricura from buffaloes (Bubalus bubalis) in Vale do Ribeira, São Paulo, Brazil. Braz. J. Microbiol., 32, 298-300. 